the entry on bookbinding itself. Since famous binders are included, other entries are biographic. Time references are often vague, such as originally, formerly, and today. Tabular information is in decimals; quantification data in the definitions are often in fractions. Lexical data are absent.

Despite such shortcomings from any one specialist perspective, this volume deserves proper credit for pulling together and synthesizing myriad data from diverse sources, offering convenience for general reference, and a pleasing presentation in legible 9 point Times Roman on quality paper, in a durable, practical binding. Every binder, bibliographer, conservator, and reference librarian will have occasion to use this tool; it is an important contribution.-Lawrence J. McCrank, Indiana State University.

\title{
OTHER PUBLICATIONS OF INTEREST
}

American Library Directory. Comp. and Ed. by Jaques Cattel Press. New York: Bowker, 1983. 2v. 2,064p. $\$ 97.50$ cloth. LC 23-3581. ISBN 0-8352-1694-2.

British Library History: Bibliography 1977-1980. Ed. by Denis F. Keeling. Phoenix, Ariz.: Oryx, 1983. 242p. $\$ 30$ paper. ISBN $0-85365-$ 805-6.

Butcher, David. Official Publications in Britain. Hamden, Conn.: Shoe String, 1983. 161p. $\$ 18.50$ cloth. ISBN 0-85157-351-7.

Censorship Litigation and the Schools. Office for Intellectual Freedom. Chicago: American Library Assn., 1983. 161p. \$17.50 paper. LC 8224458. ISBN 0-8389-3279-7.

Contemporary Subject Headings for Urban Documents. Comp. by Greenwood Press for the Urban Documents Program. Westport, Conn.: Greenwood, 1983. 106p. \$25. LC 8225504. ISBN 0-313-23869-3.

Costa, Betty, and Costa, Marie. A Micro Handbook for Small Libraries and Media Centers. Littleton, Colo.: Libraries Unlimited, 1983. 216p. \$19.50 U.S. $\$ 23.50$ elsewhere. LC 8311294. ISBN 0-87287-354-4.

Dequin, Henry C. Librarians Serving Disabled Children and Young People. Littleton, Colo.: Libraries Unlimited, 1983.303 . $\$ 22.50$ U.S. $/ \$ 27.00$ elsewhere. LC 83-5381. ISBN 087287-364-1.

Directory of College Facilities and Services for the Handicapped. Ed. by Charles S. McGeough, Barbara Jungjohan, and James L. Thomas. Phoenix, Ariz.: Oryx, 1983. 373p. $\$ 80$ cloth. LC 82-73736. ISBN 0-89774-004-1.

1983 Directory of Information Management Software: For Libraries, Information Centers, Record Centers. Comp. and ed. by Pamela Cibbarelli and others. Chicago: American Library Assn., 1983. 133p. \$45 paper. ISBN 0-91320300-9.

Ethnic Collections in Libraries. Ed. by E. J. Josey and Marva L. DeLoach. New York: Neal-
Schuman, 1983. 361p. \$29.95 cloth. LC 82 14361. ISBN 0-918212-63-4.

Herman, Edward. Locating United States Government Information: A Guide to Sources. Buffalo, N.Y.: William S. Hein, 1983. 250p. \$27.50. LC 82-83991. ISBN 0-89941-182-7.

Indexing Specialized Formats and Subjects. Ed. by Hilda Feinberg. Metuchen, N.J.: Scarecrow, 1983. 288p. \$37.50. LC 82-23155. ISBN 08108-1608-3.

Intellectual Freedom Manual. 2d edition. Office for Intellectual Freedom. Chicago: American Library Assn., 1983. 210p. \$15 paper. LC 839958. ISBN 0-8389-3283-5.

Investment Trust Yearbook 1983. Ed. by Mara M. Vilcinskas. Westport, Conn.: Quorum, 1983. 362p. \$40. ISBN 0-89930-068-5.

Japan Trade Directory 1983-84. Japan External Trade Organization (JETRO). Detroit: Gale, 1983. 1,300p. \$180 cloth. ISBN 4-8224-0184-7.

Karetzky, Stephen. Reading Research and Librarianship: A History and Analysis. Westport, Conn.: Greenwood, 1982. 385p. \$37.50 cloth. LC 80-1715. ISBN 0-313-22226-6.

Library of Congress Rule Interpretations for AACR2: A Cumulation from Cataloging Service Bulletin Numbers 11-20. Comp. by Lois Lindberg, Alan Boyd, and Elaine Druesedow. Oberlin, Ohio: Oberlin College Library, 1983. 260p. \$20/additional copies \$17 each. Order from: Alan Boyd, Oberlin College Library, Oberlin, $\mathrm{OH} 44074$.

Library Lit. 13-The Best of 1982. Ed. by Bill Katz. Metuchen, N.J.: Scarecrow, 1983. 368p. $\$ 17.50$ cloth. LC $78-154842$. ISBN $0-8108$ 1624-5.

McWilliams, Peter A. The Personal Computer Book; The Personal Computer in Business Book; and The Word Processing Book, Los Angeles, Calif.: Ballantine Prelude Press, 1983. approx. 300p. each. \$9.95 each in U.S. $/ \$ 12.95$ in Canada. ISBN 0-345-31106-X; 31294-5; 311051. 


\section{LIBRARY is taking $\mathrm{fl}$}

\section{Reviews \& Comments}

"Library Hi Tech's inaugural issue (Summer 1983) shows excellent promise."

-Information Retrieval \& Library Automation, 7/83

"Under the expert guidance of Nancy Melin, here are 120 illustrated pages which deliver what the editor claims.... What makes the articles particularly useful is the inclusion of bibliographies, often annotated.....It's hard to think of another journal with such wide coverage, such good writing, and such common sense advice for the less than expert who is invovled with the new technologies. Highly recommended."

-Bill Katz, Editor of Magazines for Libraries
"Congratulations on your Summer, first issue....I learned a lot from the feature articles, largely because most of them were written in language I can understand. They were nearly all helpful to me and encouraged me to mark their bibliographies for further reading....Articles like these - sensible, practical pieces based on actual experience -... most of us need just this at this stage of facing the computer."

-Lee Ash, Library Consultant

"Library Hi Tech's first issue was great. I read it straight through and was exhausted by all I need to keep aware of. Keep it up. The profession needs it." -Sharon Bonk, Acting Head, Technical Services State University of New York at Albany

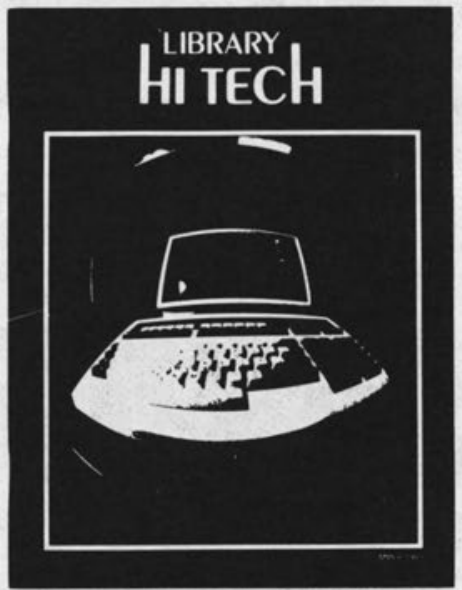

\section{Table of Contents - Fall Issue}

\section{FEATURES}

LaserData, Inc.: An Interview with Robert Nelson Acquisitions Fund Accounting on a Word Processor Dot Matrix Impact Printers: An Overview and Guide Deciphering Electronic Mail

LIAS - Library Automation with an Integrated Design EBSCONET at Cuyahoga County Public Library SOLINET's LAMBDA: Success at Tennessee Tech Michigan Information Transfer Source:

Fee-Based Information Service

Automation Programs for Archival and Manuscript Repositories Automated Circulation Systems: A Literature Survey

\section{DEPARTMENTS}

-. Printout -- Conferences - Books Reviewed/Books Received -. Software Review Index -. Database Review Index

LIBRARY HI TECH is the only journal to provide: - Comprehensive coverage of the new technologies, - Practical articles in understandable language by library practitioners and subject area specialists, - Control of the related literature appearing in periodicals, books, reports, studies, and conference proceedings. LHT evaluates, describes, and reports on the selection, installation, maintenance, and integration of systems and hardware. Each issue contains essays, literature surveys, directories, and reviews.

LIBRARY HI TECH is published quarterly. Subscriptions: Institutions: $\$ 39.50 / y r$. Individuals: $\$ 19.50 / y r{ }^{*}$ *Individual subscriptions must be paid by personal check. Postage is extra. Samples available on request.

\section{pierian press p.o. box 1808 ann arbor, mi 48106}


Mathews, Anne J. Communicate! A Librarian's Guide to Interpersonal Relations. Chicago: American Library Assn., 1983. 80p. LC 832557. ISBN 0-8389-0379-7.

Monographs in Sci-Tech Libraries. Ed. by Ellis Mount. New York: Haworth, 1983. 105p. \$20 cloth. LC 82-23435. ISBN 0-86656-218-4.

Music Directory Canada '83. Comp. by CM Books. Toronto, ON: CM Books, 1983. 252p. $\$ 19.95$ plus $\$ 1.00$ postage.

Periodical Literature on United States Cities: A Bibliography and Subject Guide. Comp. by Barbara Smith Shearer and Benjamin F. Shearer. Westport, Conn.: Greenwood, 1983. 574p. $\$ 49.95$ cloth. LC 82-24211. ISBN 0-313-235112.

Picture Sources 4. Ed. by Ernest H. Robl. New York: Special Libraries Association, 1983. 200p. \$35. LC 83-625. ISBN 0-87111-274-4.

The Present State of Scholarship in FourteenthCentury Literature. Ed. by Thomas D. Cooke. Columbia, Missouri: University of Missouri, 1983. 320p. \$23.80 cloth. LC 82-2682. ISBN 08262-0379-5.

Recommended Reference Books for Small and Medium-Sized Libraries and Media Centers 1983. Ed. by Bohdan S. Wynar. Littleton, Colo.: Libraries Unlimited, 1983. 296p. $\$ 23.50$
U.S. $\$ \$ 28.00$ elsewhere. ISSN 0277-5948. ISBN 0-87287-382-X.

Sources for American Studies. (Contributions in American Studies, Number 64, ISSN 00849227). Ed. by Jefferson B. Kellogg and Robert H. Walker. Westport, Conn.: Greenwood, 1983. 766p. \$45 cloth. LC 82-11701. ISBN 0313-22555-9.

SPEC Kits \#95, 96, 97. "Library Materials Cost Studies"; "Online Catalogs in ARL Libraries"; and "Building Renovation in ARL Libraries." SPEC Kits are available mainly by subscription from: SPEC Center, Office of Management Studies, ARL, 1527 New Hampshire Ave., NW, Washington, DC 20036. Individual kits are available for $\$ 15$ prepaid. (ARL library members receive kits for \$7.50).

Strauss, Lawrence. Electronic Marketing. White Plains, N.Y.: Knowledge Industry Publications, 1983. 141p. \$35.95. LC 83-185. ISBN 086729-023-4.

Telecommunications Systems and Services Directory. 1st edition. Ed. by John Schmittroth, Jr., and Martin Connors. Detroit: Gale, 1983. 225 p. Three-issue subscription, $\$ 150$ paper. LC 83-11628. ISBN 0-8103-1696-X.
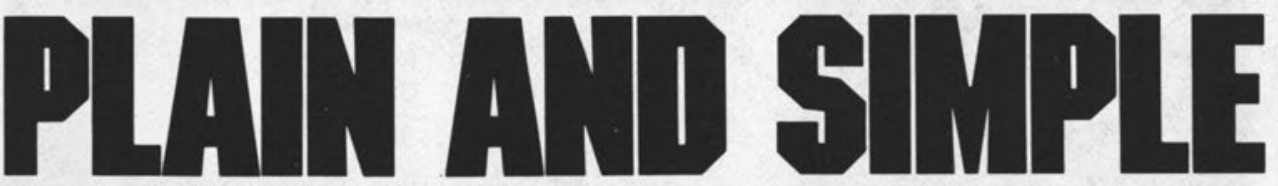

Our physical size and financial strength - necessary to make and honor commitments indicate the successful working relationships we have with thousands of libraries worldwide.

But the plain truth is, simply, that it is our sensitivity to your unique requirements, and our flexibility in providing an exhaustive and relentless effort for total customer service that is our real strength.

We want to work with you - to help you provide exceptional patron service, which is your strength.

We can help. Write today-P.O. Box 1943, Birmingham, AL 35201 (205) 991-6600 Telex 78-2661

\section{ERSCO SUESCRIPTION SERVICES}

The Serials Professionals

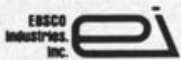

